\title{
Puccinia spegazzinii (Pucciniales: Pucciniaceae) from Peru for biological control of Mikania micrantha (Asteraceae: Eupatorieae) in India: evaluating susceptibility of host populations and confirming host specificity
}

\author{
Prakya Sreerama Kumar ${ }^{1 *}$ D, Usha Dev ${ }^{2}$ and Nidhi Joshi
}

\begin{abstract}
Mikania micrantha (Asteraceae: Eupatorieae), widely called mile-a-minute, has been a persistent problem to forestry, plantations and biodiversity conservation in southwestern and northeastern India, as well as in Andaman and Nicobar islands. To supplement the previously imported Trinidad-originating Puccinia spegazzinii (Pucciniales: Pucciniaceae), a different pathotype (IMI 393076) was imported from Peru, South America, after obtaining the import permit from the Plant Protection Advisor to the Government of India. The Peruvian pathotype was held in the National Containment-cum-Quarantine Facility for Transgenic Planting Material at ICAR-National Bureau of Plant Genetic Resources in New Delhi as a quarantine organism for pre-release evaluation. Screening of M. micrantha populations from Andaman and Nicobar islands (12), Assam (15) and Kerala (3) indicated their complete susceptibility to the Peruvian pathotype. In the host-specificity tests, the rust could not infect any of the 25 plant species in ten tribes within Asteraceae, which confirmed its safety to non-target plant species. Further, none of the 31 sunflower cultivars/ accessions screened were infected.
\end{abstract}

Keywords: Andaman and Nicobar islands, Assam, Classical biological control, Host specificity, Kerala, Mikania micrantha, Puccinia spegazzinii

\section{Background}

Mikania micrantha Kunth (Asteraceae: Eupatorieae), a rapidly growing perennial vine from the Neotropics, is widely called mile-a-minute. It is an acknowledged invasive species in the Indian subcontinent, Southeast Asia and the Pacific region (Waterhouse 1994). In southwestern India, particularly in Kerala, it has been a persistent and expanding problem in natural forests, agro-forests and plantation crops. In the northeast, its importance has escalated in the last few decades due to large-scale degradation of natural forests, from where it spread to the commercially significant tea

\footnotetext{
* Correspondence: psreeramakumar@yahoo.co.in

'Division of Insect Ecology, ICAR-National Bureau of Agricultural Insect

Resources, Bengaluru 560 024, India

Full list of author information is available at the end of the article
}

gardens (Murphy et al. 2000). In the biodiversity-rich Andaman and Nicobar islands, the unique native flora are under threat from the vegetation-smothering $M$. micrantha.

In Kerala, M. micrantha interferes with the cultivation and production of banana, coconut, coffee, cocoa, cassava, rubber, pineapple, ginger and teak. In the moist deciduous forests of the Western Ghats, the unhindered spread of $M$. micrantha makes harvesting of reed, bamboo and other non-wood forest products by tribal communities difficult. In homegarden farming systems in the Western Ghats region, M. micrantha was found to have an impact on production costs and income of all sizes of holdings, as it accounted for $10-20 \%$ of the total weeding costs (Murphy et al. 2000). On the other hand, in the northeastern state of Assam, the main concern is 
in tea plantations, especially in the light of herbicides being discouraged in this export-oriented crop. The weed has, to a considerable extent, prevented growers from swiftly changing to organic production.

Under a collaborative project between India and CABI in the UK during 1996-2000, the autoecious, microcyclic rust fungus, Puccinia spegazzinii de Toni (Pucciniales: Pucciniaceae), a common and damaging pathogen of $M$. micrantha in the Neotropics, was chosen as the most ideal candidate for introduction into India to manage the weed (Murphy et al. 2000; Sreerama Kumar et al. 2016).

Following a successful risk analysis under quarantine at CABI (UK), a pathotype of the fungus (IMI 393067) from Trinidad and Tobago was imported into India. In pre-release evaluation, the rust was further assessed under strict quarantine conditions to ascertain the susceptibility of $M$. micrantha populations from three affected regions of India and to confirm the safety of economically important plant species. Results of hostspecificity screening of 90 plant species from 32 families confirmed that the Trinidadian pathotype of $P$. spegazzinii was highly host-specific and could not infect any of the test plant species, while it was highly pathogenic to most of the target weed populations from Assam, Kerala and the Andaman and Nicobar islands (Sreerama Kumar et al. 2016).

A supplementary dossier on the additional hostspecificity tests provided the basis for obtaining the permit for release of $P$. spegazzinii from the Plant Protection Advisor to the Government of India in June 2005 (Sreerama Kumar et al. 2005).

The rust was first released in tea gardens in Assam in October 2005, but did not establish, most likely due to the presence of a biotype of the weed that was partially resistant to the Trinidadian pathotype used. In Kerala, the rust was initially released in agricultural systems, during August 2006, followed by releases at forest sites. Although on initial assessment those releases were considered to be successful because the rust had spread and persisted for a short while, there was no apparent establishment (Sankaran et al. 2008; Sreerama Kumar et al. 2016).

To supplement the Trinidadian pathotype, as well as to tackle some of the populations resistant to it, another pathotype of $P$. spegazzinii from Pilcopata in Peru was imported into India. In earlier investigations at CABI (UK), the Peruvian pathotype demonstrated broader pathogenicity towards both southwestern and northeastern populations of $M$. micrantha (Ellison et al. 2004).

The aims of the present work were to evaluate the susceptibility of $M$. micrantha populations from three different regions of India to the Peruvian pathotype of $P$. spegazzinii and to confirm its host specificity.

\section{Materials and methods}

Importation, establishment and maintenance of rust in quarantine

Bare-rooted Indian $M$. micrantha plants, inoculated in the CABI (UK) Quarantine with a previously chosen pathotype (IMI 393076) of P. spegazzinii from Peru, South America, were imported into India (vide Permit No. 85/ 2005 in PQ Form 13; date of issue: 20 December 2005) on 20 February 2006. The consignment was hand-carried and received at the New Delhi airport and immediately transferred to the CL-4 level National Containment-cumQuarantine Facility (NCQF) for Transgenic Planting Material of ICAR-National Bureau of Plant Genetic Resources (NBPGR). Out of the seven plants received (Fig. 1) and planted in pots in the NCQF on the same day of receipt, three plants wilted and the rest were able to establish and develop mature telia. The rust inoculum thus obtained was used for further multiplication of the pathotype on M. micrantha populations from Assam and/ or Kerala. The pathotype was passed several times through M. micrantha, established and maintained without hyperparasites by re-inoculation, approximately every 6 weeks, onto fresh plants that were given a standard 24-h dew period. The inoculated test plants, as well as the spent inoculum, were autoclaved and incinerated after the mandatory experimental period. Other used materials, such as protective clothing, were also destroyed in a similar manner. Used soil was autoclaved before discarding.

\section{Target weed}

Populations of $M$. micrantha in the form of young seedlings or cuttings were collected from three different regions in India (Table 1) (Sreerama Kumar et al. 2016). These comprised three populations (Chimmoni, Peechi and Vazhachal) from Thrissur district of Kerala, 15

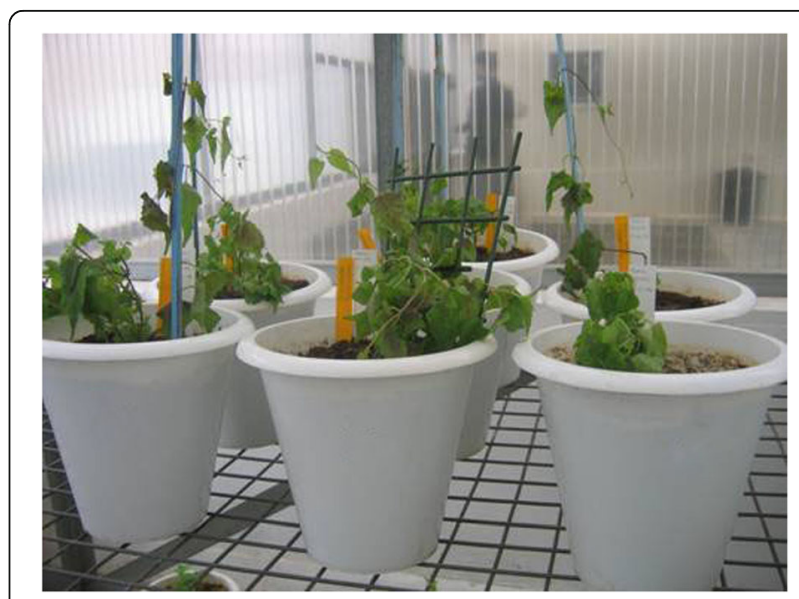

Fig. 1 Indian Mikania micrantha plants, infected with the Peruvian pathotype of Puccinia spegazzinii, transplanted into pots in the quarantine upon arrival from $C A B \mid$ 
Table 1 Susceptibility of Mikania micrantha populations from different regions in India to Puccinia spegazzinii (Peruvian pathotype)

\begin{tabular}{|c|c|c|c|c|c|c|}
\hline \multirow{2}{*}{$\begin{array}{l}\text { State/union } \\
\text { territory }\end{array}$} & \multirow[t]{2}{*}{ Place of collection/ population (district) } & \multirow[t]{2}{*}{ No. of plants inoculated ${ }^{a}$} & \multicolumn{4}{|c|}{ Pathogenicity score } \\
\hline & & & Range & Median & Mode & Mean $^{\mathrm{b}}$ \\
\hline \multirow[t]{12}{*}{$\begin{array}{l}\text { Andaman and } \\
\text { Nicobar islands }\end{array}$} & $\begin{array}{l}\text { CARI (ICAR-Central Agricultural Research Institute), Garacharma, } \\
\text { Port Blair (South Andaman) [CARI-1] }\end{array}$ & $9(1)$ & 1 & 4 & 4 & 3.63 \\
\hline & CARI, Garacharma, Port Blair (South Andaman) [CARI-2] & $7(1)$ & 1 & 4 & 4 & 3.83 \\
\hline & CARI, Garacharma, Port Blair (South Andaman) [CARI-3] & $11(1)$ & 1 & 3.5 & 3,4 & 3.50 \\
\hline & Garacharma village, Port Blair (South Andaman) & 7 & 1 & 4 & 4 & 3.71 \\
\hline & Hut Bay, Little Andaman (South Andaman) & $8(1)$ & 1 & 4 & 4 & 3.71 \\
\hline & Kalpong Hydroelectric Project Junction (North and Middle Andaman) & 8 & 1 & 4 & 4 & 3.75 \\
\hline & Kalpong (North and Middle Andaman) & 8 & 1 & 4 & 4 & 3.75 \\
\hline & Keralapuram (North and Middle Andaman) & 7 & 1 & 4 & 4 & 3.86 \\
\hline & Mount Harriet National Park (South Andaman) & $7(1)$ & 1 & 4 & 4 & 3.67 \\
\hline & Nayashahar (South Andaman) & 8 & 1 & 4 & 4 & 3.88 \\
\hline & Radhanagar, Havelock island (South Andaman) & 7 & 1 & 4 & 4 & 3.86 \\
\hline & Not labelled by the collector & $8(1)$ & 1 & 4 & 4 & 3.71 \\
\hline \multirow[t]{15}{*}{ Assam } & Diphu (Karbi Anglong) & 8 & 0 & 4 & - & $4.00[3]$ \\
\hline & Gelapukhuri (Tinsukia) & $8(1)$ & 0 & 4 & - & $4.00[2]$ \\
\hline & Jorhat (Jorhat) & 20 & 0 & 4 & - & $4.00[5,3]$ \\
\hline & Kokrajhar (Kokrajhar) & 8 & 0 & 4 & - & $4.00[1,2$ \\
\hline & Nagajanka (Jorhat) & $9(1)$ & 0 & 4 & - & $4.00[2]$ \\
\hline & North Lakhimpur (Lakhimpur) & 8 & 0 & 4 & - & $4.00[2]$ \\
\hline & Orang (Darrang) & $8(1)$ & 0 & 4 & - & $4.00[1]$ \\
\hline & Pathsala (Barpeta) & 8 & 0 & 4 & - & $4.00[3]$ \\
\hline & Sepon (Sivasagar) & 8 & 1 & 4 & 4 & 3.88 \\
\hline & Silapathar (Dhemaji) & 20 & 0 & 4 & - & $4.00[7,1]$ \\
\hline & Silchar (Cachar) & $8(1)$ & 1 & 4 & 4 & 3.86 \\
\hline & Silongoni (Nagaon) & 8 & 0 & 4 & - & $4.00[3]$ \\
\hline & Tezpur (Sonitpur) & 8 & 1 & 4 & 4 & 3.88 \\
\hline & Tihu (Nalbari) & 9 & 0 & 4 & - & $4.00[4]$ \\
\hline & Titabar (Jorhat) & $11(4)$ & 0 & 4 & - & 4.00 \\
\hline \multirow[t]{3}{*}{ Kerala } & Chimmoni (Thrissur) & 10 & 1 & 4 & 4 & 3.90 \\
\hline & Peechi (Thrissur) ${ }^{c}$ & $>100(4)$ & 1 & 4 & 4 & $3.89[6]$ \\
\hline & Vazhachal (Thrissur) & 13 & 1 & 4 & 4 & $3.85[2]$ \\
\hline
\end{tabular}

${ }^{a}$ The numeral within parentheses indicates the number of plants that did not receive sufficient inoculum and therefore escaped infection. Those plants were not considered for pathogenicity scoring

${ }^{\mathrm{b}}$ The first numeral within the square brackets indicates the number of plants in which more than $50 \%$ of the leaf/petiole was covered with pustules, and the second indicates the number of plants in which fusion of pustules was observed

'Data given for the first 100 plants tested

populations collected from as many locations in 13 districts of Assam, and 12 populations collected from ten locations representing North and Middle Andaman and South Andaman districts in Andaman and Nicobar islands. All the plants were potted and regularly propagated through cuttings in NCQF. The plants were maintained at $18 \pm 1{ }^{\circ} \mathrm{C}$ for multiplying the rust inoculum. Imidacloprid (0.004\%) (Confidor 200SL, Bayer) was judiciously sprayed to eliminate sucking pests (chiefly red spider mites).

\section{Test plant species}

Plant species closely related to $M$. micrantha within the Asteraceae were chosen for the host-specificity screening, thus satisfying the core principle of the centrifugal phylogenetic testing sequence proposed by Wapshere (1974). The list (Table 2) included 25 common and economically important plant species representing ten of the 17 tribes known in the family (Katinas 2005). Additionally, sunflower, Helianthus annuus L. (Asteraceae: Heliantheae), which was expected to react to $P$. 
Table 2 Asteraceae other than sunflower (Helianthus annuus) tested against Puccinia spegazzinii (Peruvian pathotype) and found immune to the rust

\begin{tabular}{|c|c|c|c|c|}
\hline Tribe & Scientific name & Common name & Cultivar & Source/place of collection \\
\hline \multirow[t]{3}{*}{ Anthemideae } & Artemisia annua $\mathrm{L}$. & Sweet sagewort & EC-202429 & $\begin{array}{l}\text { ICAR-National Bureau of Plant Genetic } \\
\text { Resources (NBPGR) Regional Station, } \\
\text { Bhowali, Uttarakhand }\end{array}$ \\
\hline & Chrysanthemum carinatum Schousboe & $\begin{array}{l}\text { Tricolour } \\
\text { chrysanthemum }\end{array}$ & - & NBPGR premises, New Delhi \\
\hline & Matricaria aurea Boiss. & Golden cotula & - & Gene Bank, NBPGR, New Delhi \\
\hline \multirow[t]{3}{*}{ Astereae } & Aster chinensis L. & China aster & - & Argosy Seeds, New Delhi \\
\hline & Bellis perennis $\mathrm{L}$. & Daisy & & Argosy Seeds, New Delhi \\
\hline & Brachyscome iberidifolia Benth. & Swan river daisy & - & Sunder Nursery, New Delhi \\
\hline Calenduleae & Calendula officinalis $\mathrm{L}$. & Calendula & - & NBPGR premises, New Delhi \\
\hline Cichorieae (=Lactuceae) & Sonchus arvensis $\mathrm{L}$. & Field sowthistle & - & NBPGR premises, New Delhi \\
\hline \multirow[t]{2}{*}{ Cynareae } & Carthamus tinctorius L. & Safflower & - & Gene Bank, NBPGR, New Delhi \\
\hline & Centaurea cyanus L. & Cornflower & - & Argosy Seeds, New Delhi \\
\hline \multirow[t]{3}{*}{ Eupatorieae } & Ageratum conyzoides L. & Goat weed & - & Cinnamara, Jorhat, Assam \\
\hline & $\begin{array}{l}\text { Chromolaena odorata (L.) R.M. King \& } \\
\text { H. Robinson }\end{array}$ & Siam weed & - & $\begin{array}{l}\text { Nancowry, Nicobar islands, Andaman } \\
\text { and Nicobar islands }\end{array}$ \\
\hline & Stevia rebaudiana (Bertoni) Bertoni & Sweet leaf & - & $\begin{array}{l}\text { North Eastern Development Finance } \\
\text { Corporation Limited, Guwahati, Assam }\end{array}$ \\
\hline \multirow[t]{2}{*}{ Helenieae } & Tagetes erecta $\mathrm{L}$. & Big marigold & - & NBPGR premises, New Delhi \\
\hline & Tagetes tenuifolia Cav. & $\begin{array}{l}\text { Striped } \\
\text { marigold }\end{array}$ & - & NBPGR premises, New Delhi \\
\hline \multirow[t]{7}{*}{ Heliantheae } & Cosmos bipinnatus Cav. & Cosmos & - & Argosy Seeds, New Delhi \\
\hline & Dahlia sp. & Dahlia & Unwins Mix & Namdhari Seeds Pvt. Ltd., Bidadi, Karnataka \\
\hline & Eclipta alba (L.) Hassk. & False daisy & - & $\begin{array}{l}\text { Nancowry, Nicobar islands, Andaman and } \\
\text { Nicobar islands }\end{array}$ \\
\hline & Guizotia abyssinica Cass. & Niger-seed & - & Gene Bank, NBPGR, New Delhi \\
\hline & Parthenium hysterophorus L. & Congress grass & - & NBPGR premises, New Delhi \\
\hline & Tithonia diversifolia (Hemsl.) Gray & $\begin{array}{l}\text { Mexican } \\
\text { sunflower }\end{array}$ & - & Argosy Seeds, New Delhi \\
\hline & Zinnia elegans Jacq. & Elegant zinnia & $\begin{array}{l}\text { Giant Dahlia Fld. } \\
\text { Double Mixed }\end{array}$ & Namdhari Seeds Pvt. Ltd., Bidadi, Karnataka \\
\hline Mutisieae & Gerbera jamesonii Bolus ex Hook. f. & Transvaal daisy & - & Sunder Nursery, New Delhi \\
\hline \multirow[t]{2}{*}{ Senecioneae } & Cineraria lyrata DC. & Wild parsley & Jubilee Mix & Bansal Hortica, New Delhi \\
\hline & $\begin{array}{l}\text { Erechtites valerianifolia } \\
\text { (Link ex Wolf) Less. ex DC. }\end{array}$ & $\begin{array}{l}\text { Tropical } \\
\text { burnweed }\end{array}$ & - & Cinnamara, Jorhat, Assam \\
\hline
\end{tabular}

spegazzinii (Ellison et al. 2008; Sreerama Kumar et al. 2016), was investigated more rigorously. Details of the 31 cultivars/accessions of sunflower tested for host specificity of the rust are given in Table 3 . The plants were raised (primarily through seeds) in autoclavable plastic pots, containing garden soil mixed with both organic manure and inorganic fertilisers, and seedlings were maintained for rust inoculations. All the plant collections were maintained under available natural light conditions inside designated bays at $18 \pm 1{ }^{\circ} \mathrm{C}$ until inoculations. The plants were watered at least once a day. Adequate care was taken to ensure that the plants did not harbour any insect or mite pests.
Rust inoculation and assessment of pathogenicity

The inoculation procedure described for the Trinidadian pathotype of P. spegazzinii (Sreerama Kumar et al. 2016) was adopted with slight modifications. Young, healthy seedlings of test plants were sprayed with distilled water and kept in a dew chamber (MER 625 SCN/Dew, Mercia Scientific). The inoculum, consisting of leaves with petioles and/or stem having cushions of telia (rust pustules), was spread over the grill-like tray just above the plants to be inoculated in such a manner that the pustules (for example, on the lower surface of the leaves) faced the healthy plants kept on the lower rack. A 48-h dew period at $20{ }^{\circ} \mathrm{C}$ and $100 \% \mathrm{RH}$ was used to ensure 
Table 3 Reaction of sunflower (Helianthus annuus) cultivars/ accessions to Puccinia spegazzinii (Peruvian pathotype)

\begin{tabular}{|c|c|c|}
\hline Cultivar/accession & Source & Reaction \\
\hline AHT-16 & AAU, Jorhat, Assam & $--^{\mathrm{a}}$ \\
\hline AHT-17 & AAU, Jorhat, Assam & - \\
\hline IH-662 & AAU, Jorhat, Assam & - \\
\hline$\Vdash-673$ & AAU, Jorhat, Assam & $--^{a}$ \\
\hline $\mathrm{CO}-2$ & Tamil Nadu & $++^{\mathrm{b}}$ \\
\hline CO-4 (TNAUSUF-7) & Tamil Nadu & $+^{\mathrm{b}}$ \\
\hline Swarna Hybrid & Tamil Nadu & - \\
\hline TCSH-1 (TNAU) & Tamil Nadu & $t^{a}$ \\
\hline CMSH-84A & Gene Bank, NBPGR, New Delhi & - \\
\hline LSFH-35 & Gene Bank, NBPGR, New Delhi & $+^{\mathrm{b}}$ \\
\hline PRO-011 & Gene Bank, NBPGR, New Delhi & - \\
\hline EC-512670 (France) & NBPGR, New Delhi & - \\
\hline EC-512671 (France) & NBPGR, New Delhi & $t^{\mathrm{b}}$ \\
\hline EC-512682 (France) & NBPGR, New Delhi & - \\
\hline EC-512683 (France) & NBPGR, New Delhi & - \\
\hline EC-512714 & NBPGR, New Delhi & $+^{c}$ \\
\hline EC-512716 & NBPGR, New Delhi & $+^{c}$ \\
\hline EC-512722 & NBPGR, New Delhi & $+^{c}$ \\
\hline IC-328856 & NBPGR, New Delhi & $t^{a}$ \\
\hline JBT-38/228 (IC-424494) & NBPGR, New Delhi & $t^{\mathrm{a}}$ \\
\hline KP-AK-37 (IC-415357) & NBPGR, New Delhi & - \\
\hline KP-AK-76 (IC-415396) & NBPGR, New Delhi & $+^{\mathrm{b}}$ \\
\hline KP-AK-164 (IC-415484) & NBPGR, New Delhi & - \\
\hline Morden & NBPGR, New Delhi & $--^{\mathrm{a}}$ \\
\hline MSFH-17 & NBPGR, New Delhi & $t^{a}$ \\
\hline Peridoivic & NBPGR, New Delhi & $t^{c}$ \\
\hline SM-BJ-6 (IC-411604) & NBPGR, New Delhi & - \\
\hline SM-BJ-22 (IC-411620) & NBPGR, New Delhi & - \\
\hline SM-BJ-50 (IC-411648) & NBPGR, New Delhi & - \\
\hline SM-BJ-99 (IC-411697) & NBPGR, New Delhi & - \\
\hline Surya & NBPGR, New Delhi & $+^{\mathrm{b}}$ \\
\hline
\end{tabular}

+ mild chlorotic flecks observed on leaves (pathogenicity score 1), - no chlorotic flecks observed, AAU Assam Agricultural University, Jorhat, Assam, NBPGR ICAR-National Bureau of Plant Genetic Resources, New Delhi ${ }^{a}$ Trinidadian pathotype caused mild chlorotic flecks (Sreerama Kumar et al. 2016)

${ }^{\mathrm{b}}$ Trinidadian pathotype did not cause chlorotic flecks (Sreerama Kumar et al. 2016)

${ }^{c}$ Not tested against the Trinidadian pathotype (Sreerama Kumar et al. 2016)

every opportunity for each test plant to get infected. $M$. micrantha plants from Assam were used as positive controls in the host-specificity screening. The basidiospores produced from teliospores at high humidity were ejected from the teliospores and fell on the young seedlings below. Four young plants of each test species along with four positive controls were inoculated, and each experiment was repeated twice. For some plant species, populations from more than one location were tested. Based on the symptoms produced, the following pathogenicity scores (PS) were assigned to assess the susceptibility of plants: $0=$ no macroscopic symptoms; $1=$ necrotic spots on inoculated vegetative parts-no sporulation; 2 = abnormal infection site: chlorotic patches on vegetative parts with very low teliospore production around edges of chlorosis; 3 = abnormal infection site: pustules reduced in size with low teliospore production in relation to compatible host-pathogen interaction; and $4=$ normal pustule formation, in relation to compatible host-pathogen interaction. Additionally, observations were taken on the number of plants in which more than $50 \%$ of leaf/ petiole was covered with pustules and on the number of plants in which fusion of pustules happened. The inoculated plants were monitored for approximately 6 weeks, i.e. twice the time taken for full symptoms to develop on the control plants, and, thereafter, autoclaved and incinerated.

\section{Statistical analysis}

Range, median, mode and mean of the pathogenicity scores for each population of $M$. micrantha were calculated online at www.easycalculation.com to describe the basic features of the data.

\section{Results and discussion}

On $M$. micrantha, the initial symptoms of rust were apparent 5-7 days after inoculations, as chlorotic spots on leaves, petioles and along the stem. Within $12-15$ days, the infection developed into dark orange-coloured telia with teliospores embedded in sori.

All the 12 populations of $M$. micrantha from the group of Andaman islands within the Union Territory of Andaman and Nicobar islands were found to be susceptible to the Peruvian pathotype, with the maximum mean pathogenicity score of 3.88 (Nayashahar) and the minimum of 3.50 (CARI-3) (Table 1). The rust pathotype produced normal life cycle on all the Andaman weed populations (Fig. 2).

The 15 populations of $M$. micrantha from Assam were found to be susceptible to the rust. Except Sepon, Silchar and Tezpur populations, the other 12 scored the maximum (i.e. PS 4) in pathogenicity (Table 1). The rust pathotype produced normal life cycle on the populations from Assam (Fig. 3). In contrast, there was remarkable variability in susceptibility of Assam $M$. micrantha plants towards the Trinidadian pathotype of the same rust (Sreerama Kumar et al. 2016). Even the $M$. micrantha populations from Karbi Anglong and Tinsukia that showed resistance to the Trinidadian pathotype were completely susceptible to the rust from Peru, with a median pathogenicity score of 4 . In 11 populations, more than $50 \%$ of the leaf/petiole was 


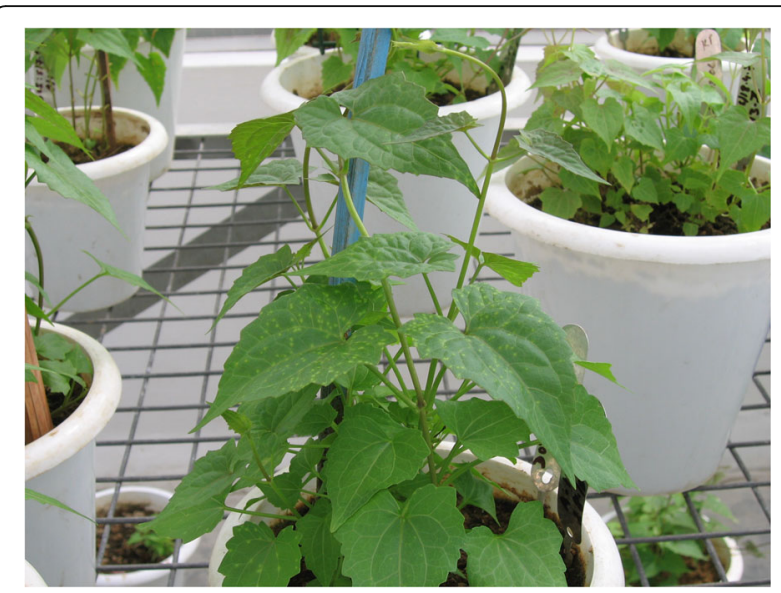

Fig. 2 A representative Mikania micrantha plant from Andaman and Nicobar islands showing early symptoms of infection with the Peruvian pathotype of Puccinia spegazzinii

covered with rust pustules. Fusion of pustules was seen only in Assam populations, specifically in those from Jorhat, Kokrajhar and Silapathar. Such fusion was not observed with the Trinidadian pathotype of $P$. spegazzinii (Sreerama Kumar et al. 2016). A comparative analysis at CABI (UK) indicated that hyperplasic canker production was high by the Peruvian pathotype but none by the

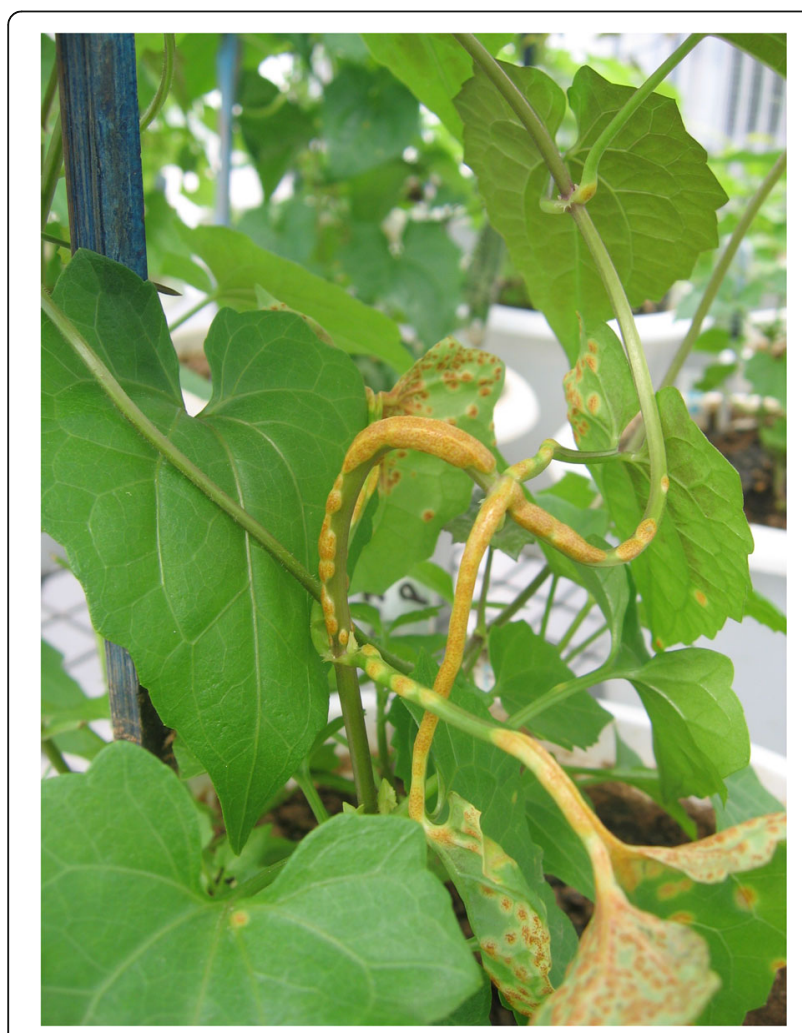

Fig. 3 A representative Mikania micrantha plant from Assam infected with the Peruvian pathotype of Puccinia spegazzinii pathotype from Trinidad (Ellison et al. 2008). Besides, the Peruvian pathotype showed a higher systemic spread than the Trinidadian pathotype. Substantial variation in aggressiveness of different $P$. spegazzinii isolates was also observed by Day et al. (2013a) in M. micrantha accessions from Fiji and Papua New Guinea (PNG).

All the three populations of $M$. micrantha from Kerala were found to be susceptible to the Peruvian pathotype with the mean pathogenicity scores of 3.90 (Chimmoni), 3.89 (Peechi) and 3.85 (Vazhachal) (Table 1). The pathogen produced normal life cycle on all the weed populations from Kerala (Fig. 4).

Twenty-five plant species, other than sunflower, belonging to ten tribes in the Asteraceae were found to be immune to the Peruvian pathotype of $P$. spegazzinii (Table 2). On the other hand, the pathogen formed normal pustules on all the positive controls.

In earlier studies with the Trinidadian pathotype, none of the 34 Asteraceae species (other than sunflower), including the present 25, reacted to the rust (Sreerama Kumar et al. 2016).

Fourteen out of the 31 sunflower cultivars/ accessions tested against $P$. spegazzinii (Peruvian pathotype) showed mild chlorotic flecks (PS 1) (Table 3) on a few top leaves that were directly below the heavy inoculum inside the dew chamber, around 6-8 days after inoculation. Out of those 14 plants, four had produced similar cholorotic flecks (Table 3) with the Trinidadian pathotype (Sreerama Kumar et al., 2016). On the other hand, six accessions that reacted against the Peruvian pathotype had not reacted to the Trinidadian pathotype, and three vice versa (Sreerama Kumar et al. 2016). Although EC-68414, a sunflower accession positive to the Trinidadian pathotype (Sreerama Kumar et al. 2016), was left out this time, four additional accessions were included and all produced chlorotic flecks with the Peruvian pathotype

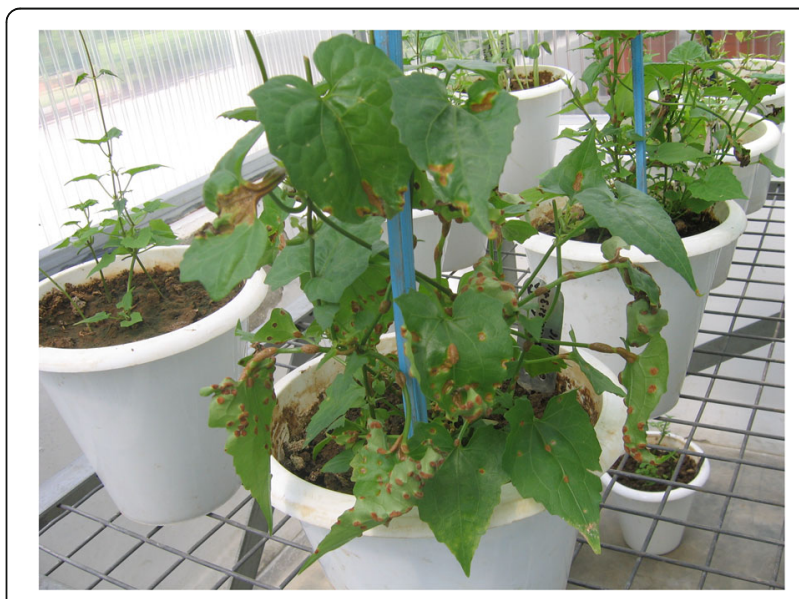

Fig. 4 A representative Mikania micrantha plant from Kerala infected with the Peruvian pathotype of Puccinia spegazzinii 
(Table 3). As expected, however, there was no sporulation in any of the cultivars/accessions. When microscopically examined, no mycelial growth was observed in the leaf tissue of the plants showing chlorotic flecks. The inoculated sunflower plants grew and flowered normally. This specific screening precluded the risk of the alien rust fungus posing any threat to sunflower cultivation in India. Ellison et al. (2008) also observed similar chlorotic flecks on sunflower in the primary host-range screening with the Trinidadian pathotype of $P$. spegazzinii in the UK. Observations till senescence indicated no mycelial growth in the leaves that exhibited chlorotic flecks.

Since ensuring host-specificity is paramount before releasing a biological agent into a new environment, $P$. spegazzinii (from Trinidad) was earlier rigorously tested and found to be safe to 55 economically important plant species in 31 families in India (Sreerama Kumar et al. 2016). After getting permission from the Plant Protection Advisor to the Government of India, the rust was first released in Assam in October 2005. The pathogen was released in Kerala initially in agricultural systems in August 2006, followed by forest sites. Kerala releases indicated potential, as the fungus was found to have spread to the native population of the weed at all sites. Field persistence, however, was observed only till December. Thereafter, microclimate at the sites was no longer appropriate for pathogen survival (Sankaran et al. 2008). Contrastingly, in Assam, the rust did not infect the M. micrantha plants in situ, possibly because of plant biotypic variation in susceptibility.

Experiences elsewhere indicate that simultaneous and sustained releases of $P$. spegazzinii at manifold locations and at appropriate time of the year could yield promising results. For example, between 2008 and 2013, an Ecuadorian pathotype of P. spegazzinii was released at multiple sites in PNG and Fiji. In PNG, from some sites, the rust had spread over $7 \mathrm{~km}$ within a year. In Fiji, the rust was established at 20 sites on two islands, i.e. Viti Levu and Vanua Levu (Day et al. 2013b). Continuous field studies in PNG indicated that $P$. spegazzinii could significantly reduce the growth and density of $M$. micrantha and offered great potential as a biocontrol agent.

\section{Conclusions}

In the present study, $M$. micrantha populations from across Assam, Kerala and Andaman and Nicobar islands were consistently found susceptible to the Peruvian pathotype of $P$. spegazzinii. In the host-specificity tests, this pathotype could not infect any of the 25 plant species, in ten tribes within the family Asteraceae indicating the safety of the pathogen. The development of chlorotic flecks on some of the 31 sunflower cultivars/accessions screened was apparently a hypersensitive reaction of no economic significance (Sreerama Kumar et al. 2016). It is deduced, therefore, that if released at an opportune time, the Peruvian pathotype of $P$. spegazzinii is expected to perform consistently in Assam, Kerala and Andaman and Nicobar islands as it is able to infect a wide range of populations of $M$. micrantha. Further, wherever required, it can be used alongside the Trinidadian pathotype.

\begin{abstract}
Acknowledgements
We would like to thank CABI for supplying the Peruvian pathotype of $P$. spegazzinii to India. Thanks are due to the Plant Protection Advisor,

Government of India, for issuing the import permit. The Director of NBPGR and the Head, Plant Quarantine Division, NBPGR, extended facilities to carry out the research work. Dr. S.T. Murphy (CABI) and Dr. R.J. Rabindra (formerly NBAIR) coordinated the project. Dr. E. Roshini Nayar (NBPGR) provided taxonomical information on test plants. Dr. R.B. Singh (NBPGR) supplied several sunflower accessions. Mr. D.K. Mishra and other project personnel at the cooperating centres provided assistance in the maintenance of plants. We gratefully thank all the scientists and officials who arranged for plants or seeds for the host-specificity tests. Dr. Prashanth Mohanraj (NBAIR) was kind enough to collect M. micrantha populations in Andaman and Nicobar islands. Special thanks are due to Dr. Carol A. Ellison (CABI) for supplying the rust inoculum and to Dr. K.V. Sankaran (Kerala Forest Research Institute) and Dr. K.C. Puzari (Assam Agricultural University) for providing M. micrantha populations from their respective states. This publication is an output from a research project (R8228) under the Crop Protection Programme, funded by the UK Department for International Development.
\end{abstract}

\section{Authors' contributions}

All authors read and approved the final manuscript.

\section{Competing interests}

The authors declare that they have no competing interests.

\section{Publisher's Note}

Springer Nature remains neutral with regard to jurisdictional claims in published maps and institutional affiliations.

\section{Author details}

${ }^{1}$ Division of Insect Ecology, ICAR-National Bureau of Agricultural Insect Resources, Bengaluru 560 024, India. ${ }^{2}$ Plant Quarantine Division, ICARNational Bureau of Plant Genetic Resources, New Delhi 110 012, India.

Received: 31 August 2017 Accepted: 18 December 2017

Published online: 22 February 2018

\section{References}

Day MD, Kawi AP, Ellison CA (2013a). Assessing the potential of the rust fungus Puccinia spegazzinii as a classical biological control agent for the invasive weed Mikania micrantha in Papua New Guinea. Biol Control, 67: 253-261

Day MD, Kawi A, Tunabuna A, Fidelis J, Swamy B, Ratutuni J, Saul-Maora J, Dewhurst CF, Orapa W (2013b) Biological control of Mikania micrantha in Papua New Guinea and Fiji using the rust fungus Puccinia spegazzinii. In: Zacharidaes C, Strathie LW, Day MD, Muniappan R (eds) Proceedings of the VIII International Workshop on Biological Control and Management of Choromolaena odorata and other Eupatorieae. 1-2 November 2010 ARCPPRI, Pretoria, South Africa, Nairobi, pp 150-157

Ellison CA, Evans HC, Ineson J (2004) The significance of intraspecies pathogenicity in the selection of a rust pathotype for the classical biological control of Mikania micrantha (mile-a-minute weed) in Southeast Asia. In: Cullen JM, Briese DT, Kriticos DJ, Lonsdale WM, Morin L, Scott JK (eds) Proceedings of the XI International Symposium on Biological Control of Weeds. CSIRO Entomology, Canberra, Australia, 27 April-2 May 2003, Canberra, pp 102-107

Ellison CA, Evans HC, Djeddour DH, Thomas SE (2008) Biology and host range of the rust fungus Puccinia spegazzinii: a new classical biological 
control agent for the invasive, alien weed Mikania micrantha in Asia. Biol Control 45:133-145

Katinas L (2005) Course on systematics and classification of Asteraceae (the Daisy family). www.botany.wisc.edu/katinas. Accessed on 29 April 2017

Murphy ST, Ellison CA, Sankaran KV (2000) The development of a biocontrol strategy for the management of the alien perennial weed, Mikania micrantha H.B.K. (Asteraceae) in tree crop based farming systems in India. Final Technical Report for DFID Project No. R 6735, unpublished document, CABI Bioscience, UK Centre (Ascot), UK, p 78 .

Sankaran KV, Puzari KC, Ellison CA, Sreerama Kumar P, Dev U (2008) Field release of the rust fungus Puccinia spegazzinii to control Mikania micrantha in India: protocols and raising awareness. In: Julien MH, Sforza R, Bon MC, Evans HC, Hatcher PE, Hinz HL, Rector BG (eds) Proceedings of the XII International Symposium on Biological Control of Weeds. La Grande Motte (Montpellier), France, 22-27 April 2007, CAB International, Wallingford, pp 384-389

Sreerama Kumar P, Rabindra RJ, Dev U, Puzari KC, Sankaran KV, Khetarpal RK, Ellison CA, Murphy ST (2005) India to release the first fungal pathogen for the classical biological control of a weed. Biocontrol News Inform 26:71N-72N

Sreerama Kumar P, Dev U, Ellison CA, Puzari KC, Sankaran KV, Joshi N (2016) Exotic rust fungus to manage the invasive mile-a-minute weed in India: prerelease evaluation and status of establishment in the field. Indian J Weed Sci 48:206-214

Wapshere AJ (1974) A strategy for evaluating the safety of organisms for biological weed control. Ann Appl Biol 77:201-211

Waterhouse DF (1994) Biological control of weeds: southeast Asian prospects. Australian Centre for International Agricultural Research, Canberra, p 302

\section{Submit your manuscript to a SpringerOpen ${ }^{\circ}$ journal and benefit from:}

- Convenient online submission

- Rigorous peer review

- Open access: articles freely available online

- High visibility within the field

- Retaining the copyright to your article

Submit your next manuscript at $\gg$ springeropen.com 